\title{
Teaching the Non-Chinese Speaking Students Origami to Improve Their Interest and Concentration in Learning Chinese Language
}

\author{
LEE Kit Fong \\ The University of Hong Kong, Hong Kong, China
}

\begin{abstract}
The difficulties in learning Chinese faced by non-Chinese students are the subjects of concern in the education sector, especially in writing Chinese characters. We write the characters with strokes and dots, more or less strokes or dots will represent different words and different meanings. Students found these very complicated and confused, thus it leads them to lose their motivation and interest in learning Chinese language. From the beginning of the 1990s, I began using origami as one of the activities to promote the teaching of Chinese in the state school in Melbourne Australia with remarkable results. Program got widely reported by Medias. In 1995, I got the "National Excellence in Teaching Awards". After I took up the position as the curriculum development officer in University of Hong Kong in 2007, I worked closely with the teachers and students using origami as the theme base learning in Chinese. It helps to increase their understanding of the radicals and parts, so as to improve their confidence in writing Chinese characters.
\end{abstract}

Keywords: non-Chinese students writing, Chinese characters, strokes and dots, origami, confidence

\section{Preface}

In recent years, with the development of China's economy and the continuous improvement of openness, more and more foreigners learn Chinese as their second language. On December 10, 2016, the 11th Confucius Institute Conference on "Innovation, Cooperation, Inclusion, and Sharing" was held. One hundred and forty countries have established 511 Confucius Institutes and 1,073 Confucius Classrooms. At present, nearly 300 institutions have been formally submitted to apply for the Confucius Institute and Confucius Classroom, and nearly 70 countries have included Chinese teaching in the national education system.

Students' learning outcomes in Chinese are directly related to teachers' classroom teaching strategies. Therefore, teachers in the classroom teaching process to stimulate students' interest in learning, improve learning motivation and effectiveness, it is worthy of academic attention to the subject.

LEE Kit Fong, B.Ed (LOTE) La Trobe University, Australia: Dip. of Teaching Melbourne University, Australia: Dip. of Teaching, Grantham College of Education Hong Kong, Curriculum Development Officer (SSP project), Faculty of Education, University of Hong Kong. 


\section{The Difficulties for the Chinese as Second Language Learners}

For the second language learners, learning to write in Chinese character seems to learn the language of the “Alien”. Many Chinese characters are very similar for the first glance. Such as the length or one stroke more; the position of a dot; the tilt of the different, students find it difficult to distinguish the difference accurately. See Table 1:

Table 1

Subtle Difference in Strokes Makes Great Difference in Meanings

\begin{tabular}{|l|l|l|l|}
\hline 晴Qíng sunny & 睛Jing eye & 人Rén person & 入Rù in \\
\hline 囚Qiú prison & 因Yīn reason & 王Wáng king & 玉Yù jade \\
\hline 折Zhé fold & 拆Chāi Demolition & 失Shī lose & 夫Fu husband \\
\hline JDiāo Unruly & 刀Dāo knife & 大Dà big & 犬Quăn dog \\
\hline 土Tǔ earth & 士Shì people & 同Tóng same & 司Sī \\
\hline
\end{tabular}

\section{Why Choosing Origami as the Teaching Tool}

To ensure the success in an origami project, the student must listen carefully to the instructions and pay very close attention to the teacher. Origami requires precision and neatness which require the student to concentrate. Also listening to the teacher's explanation helps them to increase their understanding of Chinese characters, and effectively improve their participation in the Chinese classroom learning.

\section{Compare the Visual Structure of Chinese Characters and Origami}

As with Chinese characters, a radical or component, when replaced with different parts or radicals, can be combined into a new Chinese character, see Table 2:

Table 2

Compare the Visual Structure of Chinese Character and Origami

\begin{tabular}{|l|l|l|}
\hline 漢字結構方式 The Visual Structure of Chinese Characters & 字例 Example & Origami \\
\hline 獨體結構 Single structure 口 & 口 Kǒu Mouth & \\
\hline 品字形結構品 structure 品 & 森 sēn Forest & \\
\hline 上下結構 Top Down structure $⿴$ & 思 sī Think & \\
\hline 上中下結構 Top-middle-bottom structure & 意 yì Meaning & \\
\hline
\end{tabular}


(table 2 continued)

\begin{tabular}{|c|c|c|}
\hline 漢字結構方式 The Visual Structure of Chinese Characters & 字例 Example & Origami \\
\hline 左右結構 Left-right Structure ] & 村 cūn Village & \\
\hline 左中右結構 Left-middle-right structure [I] & 街 jiē Street & \\
\hline 全包圍結構 Fully Surrounded ए & 國 guó Country & \\
\hline 左包右結構 Left surround right $\Xi$ & 醫 yī Treatment & \\
\hline 左上包右下 Left-up surround right-down & 慶 qìng Celebrate & \\
\hline 右上包左下 Right-up surround left-down $\square$ & 句 jù Sentence & \\
\hline 左下包右上 Left-down surround right-up $\square$ & 建 jiàn Build & \\
\hline 上包下 Up part surround down part п & 聞 wén Smell & \\
\hline 下包上 Down part surround up part $\square$ & 函 hán Letter & \\
\hline
\end{tabular}

Note. Retrieved from https://zhidao.baidu.com/question/88249199.html; http://www.thn21.com/base/zi/4414.html; https://www.slideshare.net/legoomandarin/the-visual-structure-of-chinese-characters-calligraphy.

\section{Compare the Base Folds of the Origami With the Basic Radicals of the Chinese Characters}

Origami has a lot of research on the understanding of mathematical geometry, and in recent years the use of origami activities in Chinese teaching has also been carried out in research.

A series of basic fold can create different graphics then finish different beautiful origami product (see Figure 1). 


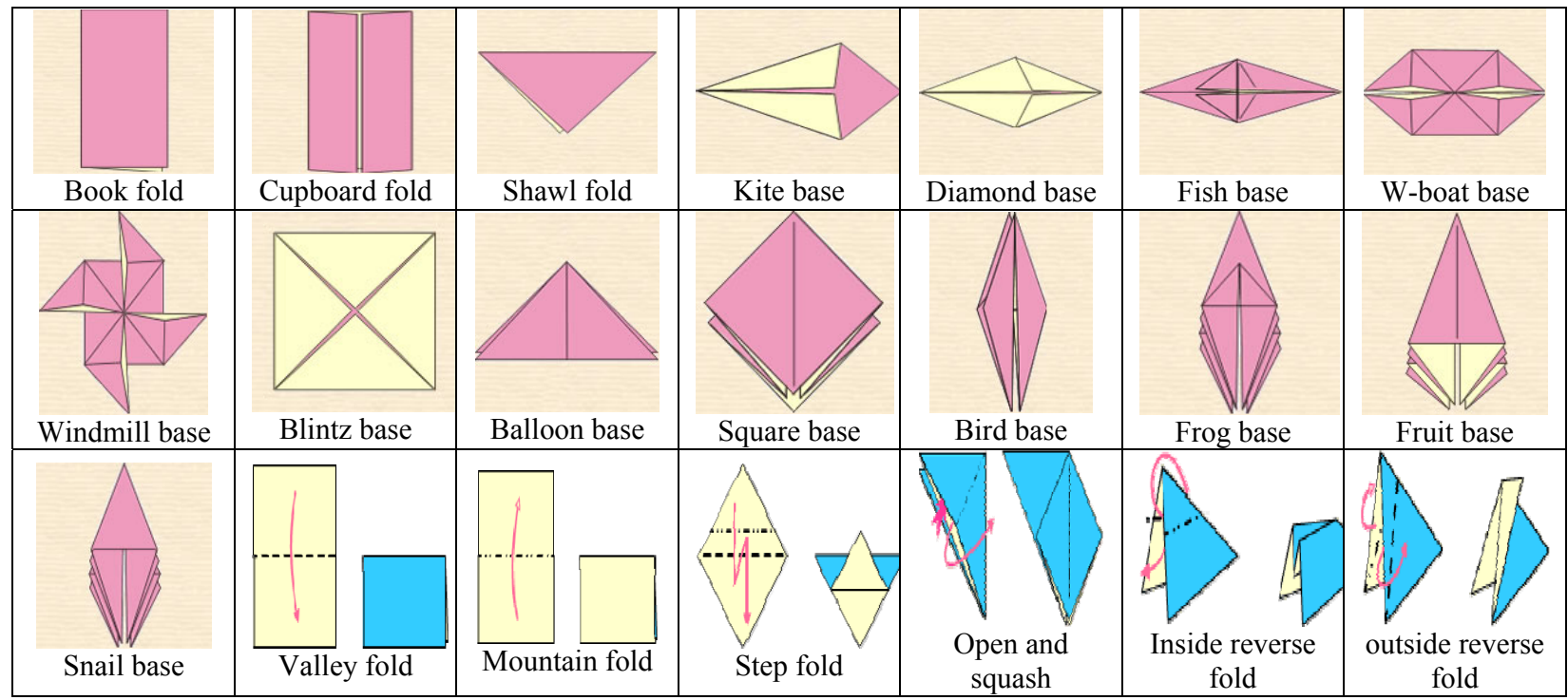

Figure 1. Origami base folds. Source: Adapted from http://www.oriland.com/oriversity/basefolds/main.php; http://www.oriland.com/oriversity/symbols/main.php.

The following are the most common radicals of the Chinese character (see Table 3):

Table 3

The Most Common Radicals of the Chinese Characters

\begin{tabular}{|c|c|c|c|c|}
\hline 人 person & 刀 knife & 力 power & 又 again & $\square$ mouth \\
\hline$\square$ enclosure & 门 door & 土 earth & 夕 sunset & 大 big, \\
\hline 女 female, & 子 son & 寸inch & 小 little & 工 work \\
\hline 鸟 bird & 弓 bow & 马 horse & 心 heart & 戈 dagger \\
\hline 手 hand & 日 sun, day & 月moon, month & 贝 shell & 木 wood \\
\hline 水 water & 火 fire & 田 field & 目eye & 示 to show \\
\hline 糸 fine silk & 耳 ear & 衣 clothing & 言speech & 走 to walk \\
\hline 足 foot & 雨 rain & 金 metal, gold & 米 rice & 食 to eat \\
\hline 車 vehicle & 虫 insect & 庐 sickness & $y$ ice & 舟 boat \\
\hline 石 stone & \# grass & 禾 grain & 竹 bamboo & 羊 sheep \\
\hline
\end{tabular}

The following are the Comparison of folding an origami car with the writing of the Chinese character "car" (see Figure 2 and Figure 3):

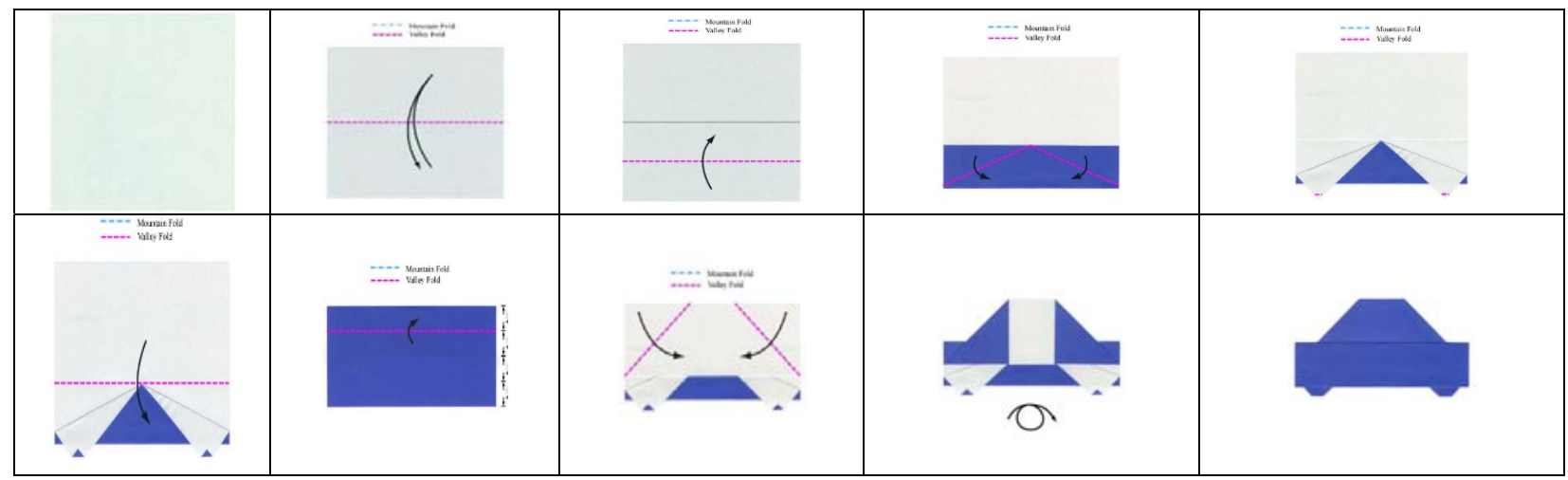

Figure 2. The folding prose of the car. Source: Adapted from http://www.origami-make.com/easy-origami-car.php. 


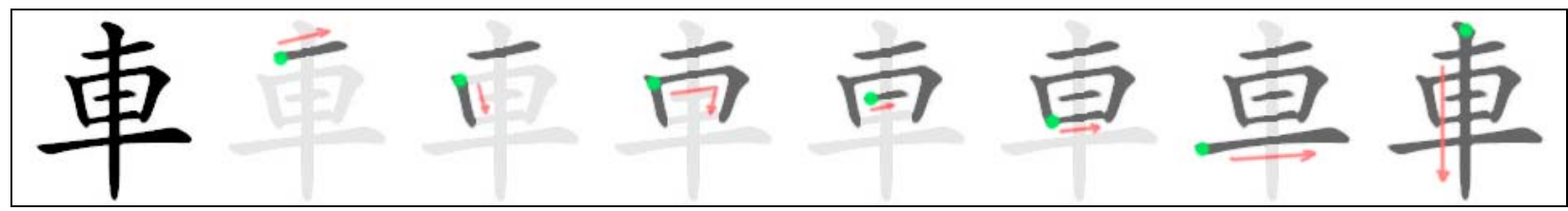

Figure 3. The stroke order of the Chinese character "car". Source: Adapted from http://www.handedict.de/jt/zi/\%E8\%BB\%8A.

\section{Is Origami Just an Interest?}

Many people think that origami is simply as an activity. We found that students through the interpretation of the origami basic folds and bases, help students understand the structure of the radicals and parts of the characters, students can clearly understand the writing of Chinese stroke orders. It helps reduce the typos of Chinese characters. See Table 4.

Table 4

The Inference of Writing Chinese Characters and Origami

\begin{tabular}{|l|l|}
\hline Chinese character structure: & Origami folding: \\
\hline 1. An image of the square & 1. Mostly use square paper \\
\hline 2. Combination of dots and lines & 2. Combination of mountain and valley fold \\
\hline 3. Writing in stroke order & 3. In a certain logical order \\
\hline 4. Each word has a specific radicals and parts & 4. Origami usually starts with a base and folds \\
\hline $\begin{array}{l}\text { 5. When writing each character, there are different image } \\
\text { changes }\end{array}$ & $\begin{array}{l}\text { 5. When folding, it appears graphics changes, like square, } \\
\text { triangle, diamond, trapezoid, polygon and others }\end{array}$ \\
\hline
\end{tabular}

\section{Origami in the Chinese Classroom}

Origami can bring out a lot of interesting classroom activities to attract students in participating in classroom teaching, improve classroom order; by participating in origami activities, in addition to students can cause interest and motivation, the teacher asked them to describe the folded works to learn a large number of Chinese vocabularies. It can enhance their oral and listening skills.

Through learning origami, students simply use the appropriate steps and order to be successful, which with the Chinese characters of the radicals and strokes have a lot of similar points.

After years of practice origami with the theme teaching, students interested in writing words also increased, students can simultaneously learn and develop their listening, reading and writing skills (see Figure 4). 


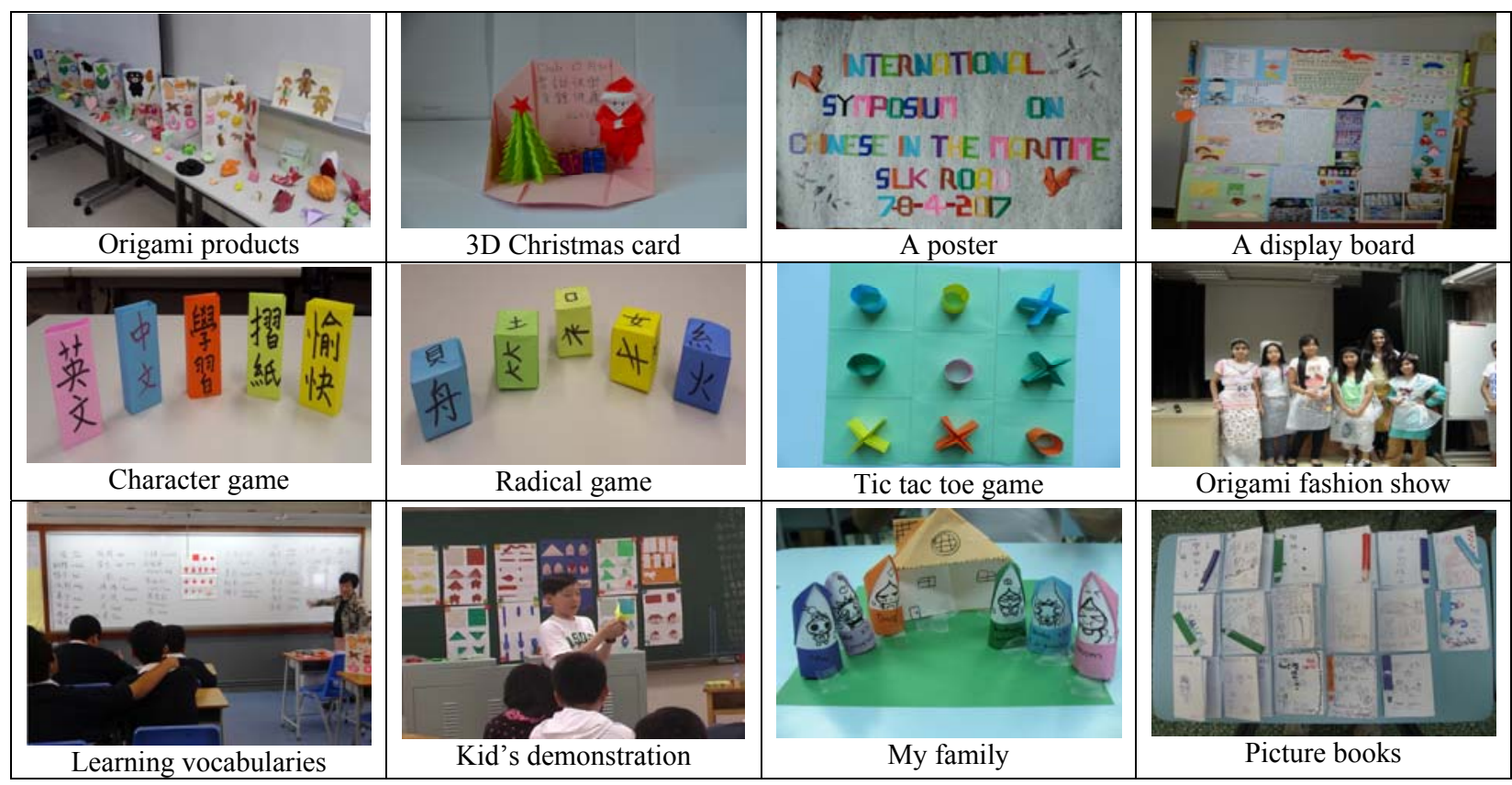

Figure 4. Using origami in the classorm.

\section{Conclusion}

It has long been known that origami has many benefits like developing eye hand co-ordination, sequencing skills, attention skills, patience, temporal spatial skills, math reasoning etc. but according to the latest research on the brain and the work of Doctor Katrin Shumakov and Yuri Shumakov, when both hands are engaged, impellent motor impulses activate the language portion of the brain.

Non-Chinese students who learn Chinese as a second language, will encounter many difficulties and problems; regardless of their problems belonging to that type, the most important thing is to improve their motivation and interest. It helps to increase their understanding of the radicals and parts, so as to improve their confidence in writing Chinese characters.

Only when the students are willing to learn, want to learn, teaching and learning effect will be obvious and fruitful.

\section{References}

Lee, K. F. (2008). Happy $\mathrm{Pa} \quad \mathrm{Ma}$ 摺 隻 Q 版小 鼠 數 學 醒 . Retrieved from http://happypama.mingpao.com/cfm/relation3.cfm?File=20080205/gaa/voalh.txt

Lee, K. F. (2014). Non-Chinese students learn Chinese with fun through origami activities. Retrieved from http://hac.education/journal/article.php? code $=26802$

Lee, K. F., \& Shan, Y. W. (2016). 趣味折紙在漢字第二語言教師培訓的應用及其成效. Retrieved from http://iscle2016.isu.edu.tw/upload/369/21/files/dept_21_1v_2_37829.pdf

Pearl, B. (2017). Origami I the classroom: Where every child counts! Retrieved from http://aboutjapan.japansociety.org/origami_in_the_classroom

Ramirez, A. (2015). Reasons why origami improves students' skills. Retrieved from https://www.edutopia.org/blog/why-origami-improves-students-skills-ainissa-ramirez

Shumakov, K., \& Shumakov, Y. (2009). Origami benefits. Retrieved from http://www.oriland.com/oriversity/benefits/main.php

Wong, S. K., Cheng, K. Y., Lee, K. F., Loh, E. F. Y., \& Tsui, S. K. (2014). Use of origami in Chinese as a second language classroom Faculty of Education, The University of Hong Kong; International Association for the Improvement of Mother Tongue Education (IAIMTE). Retrieved from http://hub.hku.hk/handle/10722/205493 